\title{
Hezhen Chinese
}

National Cancer Institute

\section{Source}

National Cancer Institute. Hezhen Chinese. NCI Thesaurus. Code C158210.

A Chinese person from the Hezhen ethnic group. 